\title{
A face disforme da Belle époque O monstruoso e a cosmovisão de Eu, de Augusto dos Anjos, e de Urupês, de Monteiro Lobato
}

Fabiano Rodrigo da Silva Santos

UNESP

\begin{abstract}
Resumo
O objetivo de nossas considerações é investigar os aspectos de Eu (1912), de Augusto dos Anjos, e de Urupês (1918), de Monteiro Lobato, que atestam uma cosmovisão sensível ao monstruoso e que se colocam em posição crítica diante dos modelos estéticos e ideológicos da Belle Époque brasileira. Publicados na década de 1910, época de modernização do país sob ideais de progressismo, eugenia e civilidade burguesa, Eu (livro de poesias) e Urupês (coletânea de contos) debruçam-se sobre aspectos evitados pela literatura oficial daqueles tempos, tais como as contradições sociais do país, as marcas de barbárie que se imprimem na história e o lado sórdido da condição humana. Tais temas ganham, nas obras, forma literária a partir de uma linguagem franca e, eventualmente, brutal que recorre ao grotesco e à ironia para efetivar uma estética de choque cuja máxima realização é o motivo do monstro. O corpo monstruoso em Eu e em Urupês (em particular no conto "Bocatorta") converte-se em privilegiada alegoria da história, expressando a orientação crítica das duas obras em relação ao contraditório processo de modernização do país.

Palavras-chave: o motivo do monstro; grotesco; alegoria; literatura brasileira; belle époque brasileira.
\end{abstract}

\begin{abstract}
The aim of these considerations is an investigation on elements of $E u$ (1912), of Augusto dos Anjos and Urupês (1918), of Monteiro Lobato, which attest a common worldview permeable to the monsters and critical to the aesthetic and ideological models of Brazilian Belle Époque. Published in 1910s, time of Brazilian modernization under the ideals of progress, eugenics and bourgeois civility, Eu (book of poetry) and Urupês (selection of short-stories) explore elements which are avoided by official literature from those times; elements as the social contradictions of the country, the spots of barbarity impressed in history and the sordid side of human condition. In Eu and Urupês, these themes receive literary form under a frank and eventually brutal language which uses the grotesque and the irony to building a shockingaesthetic which maximum realization is the motif of monster. In Eu and Urupês (particularity in the short-story "Bocatorta"), the monster's body become a privileged allegory of the History, that express the critic of these oeuvres to the contradictory process of Brazilian modernization.
\end{abstract}

Keywords: the monster motif; grotesque, allegory, Brazilian literature, Brazilian belle époque. 
1. A rigor, belle époque refere-se a período da sociedade francesa, entre a década de 1870 e o ano de 1914 (início da primeira grande guerra). Trata-se de uma época de pleno desenvolvimento da sociedade burguesa e de efervescência cultural, cujas formas artísticas típicas são representadas, sobretudo, pelo impressionismo e pelo art noveau. Fala-se em Belle époque brasileira por analogia entre a situação sociocultural do Brasil entre os anos de 1890 e 1920 e o modelo de sociedade francesa de fins do século XIX e início do XX. Uma série de fenômenos, tais como a abolição da escravatura (1888), a proclamação da república (1889), as reformas urbanas do Rio de Janeiro (iniciadas em 1902), sob Pereira Passos, a adoção de costumes burgueses etc. geram um ambiente semelhante ao da belle époque europeia, em que a arte, a literatura e os costumes contribuem formando o Zeitgeist de então, marcado por mundanismo e neofilia. Cf. NEEDELL, Jeffrey. Belle époque tropical: sociedade e cultura da elite do Rio de Janeiro na virada do século, 1993.

2. O ensaio de José Paulo Paes, "O art nouveau na literatura brasileira" (integrante, originalmente, da obra Gregos e Baianos), avalia de modo oportuno os problemas periodiológicos relativos ao período enfeixado pela designação pré-modernismo, sugerindo, como esforço de compreensão das especificidades literárias de então, sua leitura como fenômeno de uma belle époque nacional e sob orientação do art-nouveau, estilo em que se figura a tendência decorativa que perpassa em maior ou menor medida a literatura aqui produzida nas primeiras décadas do século XX. Cf. PAES, José Paulo. "O art-nouveau na literatura brasileira", 2008, p. 75-95.
Ordinariamente subestimado como um momento de estagnação de nossa literatura, oriunda da estabilização do complexo social, filosófico e estético de fins do século XIX, as primeiras duas décadas do século XX - no Brasil, nossa belle époque, época do pré-modernismo - figuram como período relegado a uma espécie de "limbo" da história literária². Valorizado apenas na condição de "antessala" do modernismo, durante muito, o interregno entre 1900 e 1920 careceu da atenção às especificidades de sua literatura, que a despeito de chancelar o triunfo da "literatura sorriso da sociedade", contou com produções singulares que fugiam ao paradigma conservador oferecido pela retórica ora mundana, ora ornamental que marca, por exemplo, a obra de Coelho Neto, Xavier Marques e Afrânio Peixoto - os grandes literatos da época. A posteridade reconheceu a expressividade de autores como Lima Barreto, Monteiro Lobato e Augusto dos Anjos (esses dois últimos, objeto de nossas considerações) - vozes emitidas do "limbo" pré-modernista, que ainda se fazem ouvir pela crítica e que normalmente são tidas como fenômenos de exceção à literatura de seu tempo.

Com efeito, Eu (1912), de Augusto dos Anjos, parece "deformar" o esteticismo de orientação parnasiana, articulando-lhe um repertório de imagens extravagantes, surgidas na zona de convergência entre o léxico precioso, o calão científico-filosófico e o vocabulário surpreendentemente vulgar, criando uma poesia de efeito, que visa não o enlevo (como na poesia do parnaso), mas o choque e a agressão. Já o livro de estreia de Lobato, Urupês (1918) ${ }^{4}$, além de operar a crítica aos estereótipos da literatura regionalista de então, conta com reiteradas intervenções irônicas de seus narradores, que colocam em xeque as convenções literárias do período, apresentando uma dicção dinâmica, econômica e contundente, que encontra local privilegiado de expressão na brevidade do conto.

Diante de tais particularidades, surge a impressão de que Augusto dos Anjos e Monteiro Lobato teriam interlocução mais adequada com as gerações futuras que com seus coetâneos, inscrevendo-se naquela categoria de autores que Alfredo Bosi reconhece como pré-modernistas não por simplesmente precederem ao modernismo, mas por anteciparem alguns de seus expedientes $^{5}$. Embora valorativos, tais juízos parecem projetar literatos inovadores da belle époque (como o são Augusto dos Anjos e Lobato) ao futuro, obnubilando a percepção das condições históricas que geraram suas obras, sobre as quais influem não apenas o repertório estético e ideológico do tempo, mas também as expectativas do público de então.

Os fatos de $E u$ ter padecido de incompreensão inicial e de Urupês ter inovado os meios de divulgação e expressão da literatura não impedem o reconhecimento de que Augusto dos 
Anjos e Monteiro Lobato foram analistas e críticos atentos à época, estando, pois, ancorados a seu contexto, sem deixar de interessar aos leitores futuros.

Os vínculos ao contexto parecem ser atestados pelo êxito público que, em menor ou maior medida, ambas as obras desfrutaram. A verdadeira revolução editorial perpetrada por Urupês ${ }^{6}$, de Lobato, demonstra a grande comunicabilidade de seu livro de contos; e até o inicialmente incompreendido Eu, de Augusto dos Anjos, em sua terceira edição, no ano de 1928, contou com surpreendente acolhida junto ao público, tornando-se um dos maiores sucessos editorais do período ${ }^{7}$. O que demonstra que o novo alento que essas duas obras trouxeram à literatura de seu tempo não escapou a seus contemporâneos, sobretudo ao público leitor anônimo, responsável imediato pelas consagrações de Augusto dos Anjos e Monteiro Lobato. Diante de tal evidência, pode-se indagar: a que se poderia atribuir o impacto de Eu e Urupês, obras tão polêmicas e aparentemente insubmissas às convenções de suas épocas, sobre a sensibilidade do público? A resposta envolve múltiplos fatores, desde a forma particular com que ambas trabalham a linguagem literária até o prisma pelo qual plasmam o fenômeno social de seu tempo. A articulação desses dois pontos permite uma síntese: muito provavelmente Eu e Urupês estão entre os livros do período que souberam traduzir de forma melhor integrada uma cosmovisão alternativa à euforia da belle époque brasileira, configurando uma espécie de laid époque, matizada por amargura e desconfiança diante do alardeado progresso da nação. Progresso esse que, entre as reformas arquitetônicas e higienistas a que Pereira Passos submeteu a Capital Federal, esbarrava com a crescente marginalização urbana, fechava os olhos ao rastro de miséria deixado no campo pela decadência dos velhos latifúndios e convivia de mãos dadas com estruturas de poder datadas do período colonial, como o patronato e o favor ${ }^{8}$.

As crônicas e os romances de Lima Barreto representam, provavelmente, a mais explícita e completa crítica a esse quadro'; contudo, Eu, de Augusto dos Anjos, e Urupês (em particular, o conto "Bocatorta"), de Monteiro Lobato, parecem sintonizar sua crítica a um motivo polarizador - uma visão da história marcada pela deformidade, precariedade e desolação, que se oferece como corpo sólido contra o qual se quebra a vaga das mistificações da belle époque. Nas duas obras, o repertório filosófico do tempo e as condições socioeconômicas do país servem de matéria-prima a uma poética de mal-estar, que encontra expressão no grotesco e máxima realização no motivo do monstro.

Aliás, o êxito editorial dos dois livros (tardio, no caso de Eu) parece dever-se um pouco a esse status de monstruosida-
3. Como observa Alfredo Bosi, a expressão "literatura sorriso da sociedade", que passou a ser associada à literatura elaborada de acordo com as expectativas de um público leitor amante da arte de efeito fácil e pouco crítica, remete a Afrânio Peixoto. Cf. BOSI, Alfredo. O Pré-modernismo, 1973.

4. Como lembra João Luís Ceccantini, embora Saci, resultado de um inquérito tenha sido publicado também em 1918, consiste em uma obra coletiva, de que Lobato é organizador. Além disso, este autor não assina seu nome, mas “Demonólogo Amador". Daí, Urupês ser considerado o livro de estreia de Monteiro Lobato. Cf. CECCANTINI, João Luís. "Cinquenta tons de verde: Urupês, o primeiro best-seller nacional", 2014, p. 51.

5. BOSI, Alfred. O Prémodernismo, 1973, p. 11.

6. Lançado em julho de 1918, Urupês teve, apenas no segundo semestre daquele ano, três edições. Sendo que os mil exemplares da primeira edição já haviam se esgotado em um único mês. As vendas da obra cresceram ao longo das edições, chegando a atingir entre a $1^{\mathrm{a}}$ edição, de 1918, e a 9ª , de 1923 , o número impressionante de trinta mil exemplares. Cf. Milena Ribeiro Martins, apud. CECCANTINI, João Luís.

"Cinquenta tons de verde: Urupês, o primeiro best-seller nacional", 2014, p. 51.

7. Como atestado da repercussão da obra de Augusto dos Anjos, Eudes Barros registra o testemunho entusiasmado de Medeiros Albuquerque de que, em 1928, Eu e outras poesias teria alcançado a venda de três mil volumes em quinze dias. Cf. Medeiros e Albuquerque, 
apud. BARROS, Eudes. A poesia de Augusto dos Anjos: análise de psicologia e estilo. 1974, p. 31.

8. Ainda no início do século $\mathrm{XX}$, pode-se observar a permanência do descompasso entre os ideais burgueses e os mecanismos de poder em vigor no país, que foram objeto das conhecidas investigações de Roberto Schwarz sobre a ficção dos oitocentos. Cf. SCHWARZ, Roberto. Ao vencedor as batatas: forma literária e processo social nos inícios do romance brasileiro. 1977.

9. BOSI, Alfredo. O Prémodernismo, 1973.

\section{O Grand-Guignol foi um} famoso teatro de Paris; fundado em 1897, era especializado em espetáculos de violência explícita que se valiam de recurso de ilusionismo para simular, em palco, cenas envolvendo eviscerações, mutilações e outras formas de horror. As apresentações do GrandGuignol repercutiram para além de França e dos espetáculos teatrais; sua estética chegou a outros países e outras formas de entretenimento, como o cinema, assumindo foros de categoria que concentra a exposição do horror e da violência. Cf. JURKOV, Tania. "Blood, Monstrosity and Violent Imagery: GrandGuignol, the French Theatre of Horror as a Form of Violent Entertainment". [sic] a journal of literature, culture and literary translation, 2013, p. 1-15.

11. FREUD, Sigmund. "O estranho", 1996, p. 242. de. Pode-se inferir que os eventos narrados ironicamente em Urupês - em que a precariedade do campo é palco para perversidades, crimes e mortes trágicas, formando um verdadeiro Grand-Guignol caipira ${ }^{10}$ - e as extravagâncias patéticas de Eu explicitaram o lado anômalo, caótico e, poder-se-ia dizer, monstruoso da realidade brasileira; lado esse recalcado naqueles tempos de reforma sociocultural. Se a literatura da belle époque deu poucos testemunhos dessa realidade, o público que acolheu as obras de Augusto dos Anjos e de Monteiro Lobato muito provavelmente as compreendia de perto. Se pudermos concentrar as expectativas, ideologias e sensibilidades da belle époque brasileira em uma espécie de psicologia coletiva, seria possível arriscar dizer que a cosmovisão de Eu e alguns aspectos de Urupês relacionam-se com ela como a categoria do Unhemlich ("Estranho" em tradução corrente em língua portuguesa), definida por Sigmund Freud, relaciona-se com a psique individual.

Segundo o ensaio "Das Unheimlich" (1919), monstros, fantasmas, corpos mutilados, dentre outras figurações sinistras que assombram a imaginações humana seriam emanações, no caso de indivíduos, de experiências reprimidas no processo de amadurecimento da psique ou, na esfera coletiva, reminiscências de sistemas de crenças arcaicas que se creem superados. Assim, por exemplo, as fantasias de ser enterrado vivo poderiam ser representações inconscientes do desejo de retorno ao útero materno, bem como o medo de fantasmas, ressonância da antiga crença de que não há fronteiras bem definidas entre o mundo dos vivos e o dos mortos. Nas palavras de Freud:

Em primeiro lugar, se a teoria psicanalítica está certa ao sustentar que todo afeto pertencente a um impulso emocional, qualquer que seja a sua espécie, transforma-se, se reprimido, em ansiedade, então, entre os exemplos de coisas assustadoras, deve haver uma categoria em que o elemento que amedronta pode mostrar-se ser algo reprimido que retorna. Essa categoria de coisas assustadoras construiria então o estranho [Das Unheimlich]; [...] esse estranho não é nada novo ou alheio, porém algo que é familiar e há muito estabelecido na mente, e que somente se alienou desta através do processo da repressão. Essa referência ao fator da repressão permite-nos, ademais, compreender a definição de Schelling do estranho como algo que deveria ter permanecido oculto, mas veio à luz. ${ }^{11}$

Pode-se pensar que o processo de modernização da sociedade brasileira das primeiras décadas do século XX deliberadamente reprimiu, sob sua bandeira higienista, eugênica e progressista, todo o conteúdo de miséria, incoerência e "feiura" que se imprime como parte inalienável da história do país. Urupês, ao oferecer a violência e a pobreza do campo como antídotos ao 
sertanista idílico em voga na literatura regionalista de então, visita alguns "traumas" da sociedade brasileira que se quer urbana e civilizada; e Augusto dos Anjos, ao "profanar" os sistemas de pensamento de sua época, encontrando, por exemplo, notas de fatalismo místico no evolucionismo, e ao ferir o decoro da poesia parnasiana com sua linguagem esdrúxula, opera o mesmo movimento que Lobato, não apenas em relação à história social, mas também no que compete aos modelos estéticos e filosóficos então aceitos.

O olhar universalista de Eu não deixa de reconhecer o quinhão local da dor cósmica esquadrinhada a partir da subjetividade hiberbólica que enfeixa a obra. Algo perceptível no poema "Os doentes". A “cidade dos lázaros", evocada na primeira parte do poema, em que perambula o eu lírico com a sensação de ter sob os pés, na terra em que pisa, "um fígado doente que sangrava / e uma garganta de órfão que gemia", pode ser interpretada como alegoria do próprio país. É nessa "urbe natal do Desconsolo" que o poeta tem a epifania da dor universal resumida em si próprio: "E vi em mim, coberto de desgraças, / o resultado de bilhões de raças / Que há muitos anos desapareceram"12.

A herança genética que configura o eu, como se verá ao longo do poema, materializa-se na galeria monstruosa de vítimas do processo histórico, que envolve os tísicos e demais doentes (que não se limitam aos hospitais, amontoando-se em todos os espaços evocados pelo poema), "as negras desonradas pelos brancos"13 e, inicialmente, o índio:

\section{$[\ldots]$}

Aturdia-me a tétrica miragem

De que, naquele instante, no Amazonas,

Fedia, entregue a vísceras glutonas,

A carcaça esquecida de um selvagem.

A civilização entrou na taba

Em que ele estava. O gênio de Colombo

Manchou de opróbrios a alma do mazombo,

Cuspiu na cova do morubixaba!

E o índio, por fim, adstrito à étnica escória,

Recebeu, tendo o horror no rosto impresso,

Esse achincalhamento do progresso

Que o anulava na crítica da História!

Como quem analisa uma apostema,

De repente, acordando na desgraça,

Viu toda a podridão de sua raça...

$\mathrm{Na}$ tumba de Iracema!...
12. ANJOS, Augusto dos. Eue outras poesias, 2010, p. 122.

13. Ibidem, p. 134. 
15. BENJAMIN, Walter. Origem do drama trágico alemão, 2013, p. 176.
A miragem do cadáver do índio surge como alegoria compreensível, nos termos de Walter Benjamin, como percepção e representação da história enquanto ruína "arquitetada" pela sucessão de barbáries e pela alienação da experiência. A representação alegórica da história opõe-se, segundo o mesmo autor, à pretensão romântica de aproximar a expressão do ideal, mediante a integração perfeita representada pelo símbolo. Em suas palavras:

Enquanto no símbolo, com a transfiguração da decadência, o rosto da natureza se revela fugazmente na luz da redenção, na alegoria o observador tem diante de si a faccies hippocratica da história, como paisagem final petrificada. A história, com tudo aquilo que de início tem em si de extemporânea, de sofrimento e de malogro, ganha expressão na imagem de um rosto - melhor, de uma caveira. ${ }^{15}$

Desse modo, a consciência histórica justifica-se como tal quando reconhece a atuação deletéria da barbárie e da alienação sobre os ideais da cultura. Reconhecer a faccies hippocratica da história implica constatar a impossibilidade do símbolo romântico (unidade absoluta entre empiria e idealidade) e assumir que a representação dos fenômenos do mundo é um constante e difícil exercício que exige, no caso dos poetas, a invenção de um código particular que, quando consciente, torna-se inevitavelmente melancólico.

Em seu esforço de investigação do triunfo da barbárie progressista sobre a civilização indígena, Augusto dos Anjos evoca alguns lugares-comuns do romantismo, como os presentes na poesia de Gonçalves Dias e na ficção de Alencar, que reconhecem, no momento de nascimento da nação, o eclipse de uma era mítica dos índios, intuída e engendrada apenas pela literatura. Contudo, Augusto dos Anjos posiciona-se criticamente diante dessas referências, parodiando-as, de certo modo, a ponto de profaná-las. A carcaça sórdida do índio a feder na floresta é a alegoria que concentra esse embate entre civilizações; a partir dela, desdobra-se um sistema de imago mortis, "a cova" do chefe tribal - o "morubixaba" - é cuspida pelo gênio de Colombo, e a tumba de Iracema converte-se na vala comum de toda a raça indígena, ou seja, os mitos e símbolos da nacionalidade cunhados pelo indianismo são mausoléus que encerram os ossos de um povo massacrado; ossos esses que o poema de Augusto dos Anjos exuma para evidenciar a exclusão da história brasileira desse tronco de onde idealmente se quis que brotasse nossa 
identidade. A alegoria de Augusto dos Anjos é contundente: o Brasil não nasce do índio, mas de seu extermínio, e o indianismo romântico não passa de triste mistificação.

Cadáveres expostos e túmulos profanados conferem forma monstruosa à visão da história para Augusto dos Anjos; considerando-se a permeabilidade que a poesia de Eu demonstra diante das teses evolucionistas do tempo, o passado de massacre e escravidão de nações, que gera a história do Brasil, como sugere "Os doentes", inscreve-se no código genético de todos os brasileiros, em particular do próprio Augusto dos Anjos que se reconhece em muitos poemas como herdeiro de uma fatalidade biológica e histórica.

Essa fatalidade hereditária também pesará sobre o monstro que figura em "O lázaro da Pátria":

Filho podre de antigos Goitacases,

Em qualquer parte onde a cabeça ponha,

Deixa circunferências de peçonha,

Marcas oriundas de úlceras e antrazes.

Todos os cinocéfalos vorazes

Cheiram seu corpo. À noite, quando sonha,

Sente no tórax a pressão medonha

Do bruto embate férreo das tenazes.

Mostra aos montes e aos rígidos rochedos

A hedionda elefantíase dos dedos...

Há um cansaço no Cosmos... Anoitece.

Riem as meretrizes no Casino,

E o Lázaro caminha em seu destino

Para um fim que ele mesmo desconhece! $!^{16}$

Espécie de simulacro distorcido da sensibilidade lírica, o lázaro da pátria materializa no corpo monstruoso todas as angústias que permeiam Eu. $\mathrm{Na}$ condição de "filho podre de antigos Goitacases", o lázaro traz a herança genética deixada pela tragédia da aniquilação dos indígenas; eis aí sua brasilidade, reforçada desde o título pelo qualificativo "da pátria”. O lázaro é o produto excêntrico, resultado patológico, de seu meio.

Embora integrado ao país, seu corpo disforme é a exteriorização de uma singularidade extrema, que, impossível de ser ignorada, isola-o - sua cabeça deixa resíduos mórbidos por onde repousa; monstros com cabeça de cão ("cinocéfalos") são atraídos por seu cheiro; a noite não lhe oferece consolo, pois é quando "as tenazas" das angústias o acometem.

Despido da monstruosidade, o lázaro revela-se como a própria sensibilidade lírica de $E u$; trata-se de indivíduo atormentado, apartado de qualquer alteridade, seja do meio que o
16. ANJOS, Augusto dos. Eu e outras poesias, 2010, p. 99. 
17. Ibidem, p. 193.

18. FRIEDRICH, Hugo.

Estrutura da lírica moderna, 1978.

19. BERARDINELLI, Alfonso. Da poesia à prosa, 2007. engendra, representado no poema pela evocação elíptica da pátria e pelas "meretrizes que riem "no Cassino", seja do próprio cosmo, cujo "cansaço" revela a aridez, a exaustão e a ressonância do vazio que cerca tudo o que existe. Por isso, a trajetória do lázaro revela-se como errância cega - diante da impossibilidade da integração com o meio e da sondagem de uma unidade metafísica que traduza a ordem cósmica, resta-lhe apenas vagar ao desconhecido, envolto pelo isolamento e pelas incertezas comuns à consciência moderna. Em sua patética condição, o lázaro é também um espetáculo de monstruosidade, ele "mostra aos montes e aos rígidos rochedos / a hedionda elefantíase dos dedos", que surge como exteriorização de sua miséria. Em poema posterior a Eu, Augusto dos Anjos reconhecer-se-á como o "poeta do hediondo"17, revelando uma autoconsciência que irmana monstruosidade e poesia. Com efeito, a leitura de "O lázaro da pátria", à luz da sensibilidade que enfeixa a poesia de Augusto dos Anjos, permite interpretar o monstro retratado nesse poema como alegoria do próprio poeta. Consciente de que entre suas misérias há uma parcela herdada do meio, assediado em sua solidão por tormentos íntimos e sensível à ressonância de vazio que cerca o cosmo, o poeta de Eu emite seu parecer sobre a existência por meio de uma poesia dissonante, excêntrica - é precisamente ela a elefantíase dos dedos exposta ao mundo. Assim, a dissonância da poesia de Augusto dos Anjos assume a forma de um corpo dissonante - daí "O lázaro da pátria" ser a perfeita síntese de uma poética do monstruoso.

Hugo Friedrich, em seu clássico Estrutura da lírica moderna, reconhece uma vertente da poesia europeia praticada a partir da segunda metade do século XIX que, ao reconhecer a ausência de lugar ao poeta na sociedade utilitária burguesa, responderá a essa condição de excentricidade com um código poético exclusivo, hermético, que se configura como nota dissonante diante das convenções de gosto ${ }^{18}$. Dessa poesia provém o cultivo das categorias negativas, do discurso oblíquo, que chega aos extremos de uma estética hermética e/ou de choque. Segundo a leitura de Friedrich, a dissonância seria um dos componentes fundamentais da poesia moderna.

Embora, como aponta Berardinelli ${ }^{19}$, a categoria da dissonância de Friedrich não contemple a generalidade da poesia moderna, não se pode negar a filiação direta de Augusto dos Anjos a essa tradição, que tem referência em Baudelaire, um dos principais "faróis" da poesia de Eu, sobretudo no que tange a sua estética de choque que se materializa no monstruoso. O soneto "O Lázaro da Pátria" (e os variados matizes do lirismo de $E u$ ) faz pensar, particularmente, na famosa declaração de Arthur Rimbaud (ilustre discípulo de Baudelaire), presente na carta endereçada a Paul Demeny, uma das famosas Cartas do 
vidente (1871), sobre o processo de conversão da sensibilidade comum em percepção poética:

La première étude de l'homme qui veut être poète est sa propre connaissance, entière. Il cherche son âme, il l'inspecte, il la tente, l'apprend. Dès qu'il la sait, il la doit cultiver: cela semble simple: en tout cerveau s'accomplit un développement naturel; tant d'égoïstes se proclament auteurs; il en est bien d'autres qui s'attribuent leur progrès intellectuel! - Mais il s'agit de faire l'âme monstrueuse: à l'instar des comprachicos, quoi! Imaginez un homme s'implantant et se cultivant des verrues sur le visage. Je dis qu'il faut être voyant, se faire voyant. ${ }^{20}$

Para Rimbaud, tornar-se poeta implica um mergulho profundo na própria subjetividade, com o intuito de promover uma forma de transfiguração que tem em seu fim o desenvolvimento de uma mirada vidente. Antes de alcançar a vidência, contudo, é necessário que o poeta torne sua alma monstruosa, "cultive verrugas em seu próprio rosto". Deformando-se, o poeta singulariza a si e ao seu olhar; por meio do desregramento dos sentidos (dirá Rimbaud adiante), dá-se a constatação do objeto da vidência: o "novo", o mesmo "nouveau" que Baudelaire, no poema "Le voyage", buscara no fundo do abismo ${ }^{21}$, traduzindo a experiência poética moderna como processo de precipitação no desconhecido.

De acordo com esses preceitos, o poeta vidente é antes um monstro; algo intuído pela lírica visionária e agressiva de Augusto dos Anjos, que encerra sua percepção agonizante da condição humana na entidade do corpo disforme. Em outro soneto, "Solilóquio de um visionário", Augusto dos Anjos encontra na autodevoração dos olhos a condição da vidência: "Para desvirginar o labirinto / Do velho metafísico Mistério, / Comi meus olhos crus no cemitério / Numa antropofagia de faminto"22. Duas monstruosidades, canibalismo e automutilação, permitem o acesso ao "Mistério". Não fortuitamente o ambiente da epifania é o cemitério; na cosmovisão de Eu, a morte e, principalmente, a putrefação (sua face material) surgem como representação concreta tanto do fatal princípio de perecimento, que une todos os organismos, como do inexorável Nada, que paira absoluto nos céus modernos, despovoados pelo empirismo científico.

O poeta visionário de um mundo reduzido à materialidade pela crise da metafísica está confinado à realidade concreta do corpo mutilado, putrefato e/ou deformado, corpo esse que não apenas surge como metáfora adequada de sua condição de singularidade, como também de sua integração com o cosmo (material e continuamente agonizante), por meio do canto (dissonante e incômodo).
20. RIMBAUD, Arthur. CEuvres complètes, 1972, p. 260.

21. BAUDELAIRE, Charles. Les Fleurs du Mal, 1942, p. 245.

22. ANJOS, Augusto dos. Eu e outras poesias, 2010, p. 120. 
23. Ibidem, p. 154.

24. Baudelaire, Charles. Les Fleurs du Mal, 1942, p. 230-231.

25. "Abel et Caïn", de Baudelaire, apresenta o contraste entre a raça de Abel, depositária de todas as benesses da atenção do Criador, e a raça de Cain, negligenciada pela graça divina, entregue à fome, à privação. Ao fim do poema, a raça de Cain se revolta, ascende aos céus e destrona Deus. Dolf Oehler, sensível à leitura que Walter Benjamin faz do conteúdo social da poesia de Baudelaire, interpreta "Abel et Caïn" como uma alegoria da revolta dos oprimidos, encontrando no poema inclusive ressonâncias da revolução de 1848. Cf.

OEHELER, Dolf. Quadros parisienses (1830-1848): estética anti-burguesa em Baudelaire, 1997.

26. PAES, José Paulo, "Uma microscopia do monstruoso", 2008b, p. 96-104.
Assumir-se monstro implica recolher-se à margem, seja da sociedade, seja, talvez mais, da própria vida. Dentro da perspectiva cósmica particular a Eu e da concepção evolucionista, em voga em seu tempo, tal recolhimento se dá junto aos estratos subterrâneos para onde foram relegados os seres mais inferiores da hierarquia natural. Em tais instâncias, a poesia de Eu encontra toda uma galeria de seres que formam um comovente espetáculo de horrores e que encontram voz no eu lírico, ao passo que também o refletem: o consórcio da subjetividade poética com essas alteridades desviantes forma uma estranha confraria de excluídos, deslocados e marginais. Alguns poemas, como "Noites de um Visionário", explicitam a preocupação da lírica de Augusto dos Anjos em integrar o eu lírico às existências desprezadas, tornando-o porta voz da dor e da revolta universais:
E no estrume fresquíssimo da gleba
Formigavam, com a simplice sarcode,
O vibrião, o ancilóstomo, o colpode
E outros irmãos legítimos da ameba!
E todas essas formas que Deus lança
No Cosmos, me pediam, com o ar horrível,
Um pedaço de língua disponível
Para a filogenética vingança! ${ }^{23}$

Como se pode notar, os organismos que vivem no mais miserável dos ecossistemas (o estrume) aqui reclamam por uma voz que os vingue - a voz do poeta, manifestada em uma metáfora inquietante e violentamente concreta -, "um pedaço de língua". Esse pedaço é justamente a poesia que não canta, mas, como no célebre "Abel e Caïn"24, de Baudelaire, blasfema, protesta e agride a ordem estabelecida ${ }^{25}$ (em sua máxima manifestação representada por Deus), conferindo voz ao coro formado por todos os marginais (o poeta incluso) que foram silenciados e confinados na condição de monstros.

Em "uma microscopia do monstruoso", José Paulo Paes interpreta a constante referência a organismos microscópicos, feita por Augusto dos Anjos, como tentativa de aclimatar o apelo do monstruoso à perspectiva evolucionista da ciência de seu tempo. A microbiologia do século XIX revela um novo universo de monstros ínfimos que serão introduzidos pelo evolucionismo na genealogia do homem. Tal fenômeno coloca em evidência aqueles pontos em que o humano confina com o bestial, explorados amiúde pelas representações dos monstros e cuja origem remete ao zoomorfismo animista das religiões arcaicas, posteriormente demonizado pelo cristianismo ${ }^{26}$.

A vantagem do uso dos novos monstros da microscopia para uma estética de choque como a de Augusto dos Anjos 
parece advir de sua veracidade científica, amparada pelos postulados do evolucionismo, que liga os microrganismos mais ínfimos ao homem, revelando as zonas de sombra no humanismo. Daí surge a inquietante constatação daquilo que une o verme ao cidadão de bem - uma espécie de monstruosidade inerente à própria realidade orgânica. Em Augusto dos Anjos, essa constatação da monstruosidade vital é componente de sua mirada visionária e, mais do que isso, parece fornece-lhe uma plataforma de revolta contra a opressão exercida por uma noção higienista de humanidade que separa o homem dos animais e o corpo civilizado do cadáver putrefato. Formando uma espécie de $\operatorname{Vanitas}^{27}$ moderno, Augusto dos Anjos integra organismos abjetos à tradicional panóplia do macabro, própria a esse gênero, compondo imagens teratológicas que expõem o lado sórdido do homem, que se envaidece do humanismo e da história, que alardeia os benefícios do progresso.

Embora não se furte a trair as marcas do lugar social específico e das experiências particulares que o engendram (a saber, o Brasil dos primeiros anos do século XX e o indivíduo Augusto dos Anjos), o discurso de Eu aspira à universalidade. Ângulo diverso é adotado por Monteiro Lobato em Urupês para evidenciar, apropriamo-nos da terminologia de Benjamin, a "facies hippocratica" da história. Enquanto Augusto dos Anjos encontra em si o microcosmo de uma monstruosidade universal, Monteiro Lobato observa os fenômenos repugnantes como uma alteridade, mas como um outro incomodamente próximo.

Urupês tange de modo explícito a uma realidade mais chã e imediata - a do Brasil que, na década de 1910, experimenta, enfim, um contraditório processo de modernização, e cuja elite social, em sua relação fetichista com os discursos de progresso e eugenia (de que não se isentou, aliás, o próprio Lobato), evita confrontar as realidades da miscigenação racial, do "atraso" socioeconômico do país e do recente passado escravagista que ainda deixa marcas sobre as relações sociais.

A literatura então em voga, na tentativa de contribuir ao "recalque" de tais fenômenos, tende a celebrar de modo algo mundano e superficial os poucos avanços que o país atingia, àquela altura, em direção ao modelo de sociedade burguesa europeia. As mentalidades oficiais da época cultivaram a ilusão de que a abertura de belas alamedas no Rio de Janeiro dariam passagem à locomotiva do progresso, de que a existência de obras literárias compostas de acordo com os mais sofisticados volteios retóricos asseguraria o desenvolvimento de uma cultura letrada efetiva, de que o desenvolvimento de uma visão idílica do campo dignificaria os alicerces rurais de nossa sociedade e de que a política e o discurso do "embranquecimento" racial aproximariam nossa gente das "raças superiores" da Europa. Urupês
27.Vanitas, cuja designação remete ao verso dos Eclesiastes: Vanitas vanitatem omnia vanitas ("vaidade das vaidades, tudo é vaidade"), consiste em tipo de natureza morta bastante difundida no século XVII, sobretudo na pintura germânica e flamenga, que, com objetivo de condenar a vaidade, evoca a imagem na morte. Um Vanitas normalmente apresenta objetos mundanos ou ligados ao poder temporal, como taças, livros, punhais, espelhos, algibeiras, geralmente em desalinho ou corroídos, dispostos ao lado de símbolos da transitoriedade da vida, como velas apagadas, flores murchas, alimentos corrompidos etc. $\mathrm{Na}$ disposição de tais objetos, sempre recebe destaque uma caveira. Cf. KOOZIN, Kristine. The Vanitas Still Lifes of Harmen Steenwick (1612-1656): Metaphoric Realism, 1990. 
volta os olhos para as esferas à margem de tais mistificações e depara-se com a realidade crua do campo.

O que, de fato, confere unidade aos contos de Urupếs é uma ironia aguda, muitas vezes virulenta, que se vale do humor negro e da caricatura como formas de delinear os indivíduos e o ambiente, predominantemente rural, que os circunda, a partir da articulação de elementos próprios da tradição da sátira a outros comuns à narrativa moderna, como o recurso do mis en abîme, da estruturação dos contos em unidades de efeitos, do pendor para descrições econômicas em que abundam sinédoques, etc. Em muitos contos, além dessa orientação, os motivos da doença, da violência, da tragédia e da perversidade surgem como componentes de uma cosmovisão específica.

Em "O engraçado arrependido", assassinato e suicídio unem-se incomodamente ao motivo do riso; em "A vingança da peroba", a indolência e a ignorância atribuída ao caboclo resultam na morte acidental de um menino, revestida por sugestões fantásticas; "Meu conto de Maupassant" apresenta relatos crus de matricídio e suicídio; a trama de "Pollice Verso" envolve um jovem médico sádico que enriquece às custas do sofrimento e do deliberado assassinato de um cliente; em "Bucólica", o desencanto da visão idílica do campo é construído ao sabor do contato com a miséria do camponês, tendo como ponto ápice o relato da morte por abandono de uma criança deficiente; o narrador de "O mata-pau" encontra no vegetal parasita, que se nutre da morte da árvore hospedeira, uma alegoria adequada à trágica história de um casal de caboclos que, ao adotar um enjeitado, acaba por selar seu destino, vindo, no futuro, a ser vítima da traição do filho adotivo; "O estigma", eco longínquo de "O gato preto" de E. A. Poe, apresenta um enredo em que um sinal que lembra um ferimento de bala trazido por um bebê ao nascer denuncia o assassinato cometido por sua mãe quando o tinha no ventre. Por fim, "Bocatorta" concentra e acentua o caráter inquietante da atmosfera que perpassa os outros contos, ao narrar a história de uma fazenda, notabilizada por um pântano insidioso, que se torna palco de um pesadelo real, envolvendo superstições, coincidências trágicas, necrofilia e a figura de um monstro local, um negro severamente deformado que lá vive sob a alcunha de Bocatorta.

Os demais contos não parecem integrar perfeitamente esse "sistema" de representação do campo sob a ótica do crime e da monstruosidade: "Os faloreiros" traz uma história de crimes que se passa em um farol e não no campo; "O comprador de fazendas" apresenta a sátira às ambições mesquinhas dos fazendeiros arruinados; "Colcha de retalhos" consiste em um comovente registro da inocência perdida, a que não faltam notas irônicas; e "Um suplício moderno" denuncia as condições humilhantes 
em que vivem os estafetas por meio de uma narrativa ilustrativa. Esses últimos contos, embora marcados pela precariedade que Lobato expõe como "cor local” dos sertões brasileiros, não chegam aos extremos do registro de crimes, mortes e perversidades. A tragédia que os perpassa é muito mais cotidiana.

Em linhas gerais, o universo de Urupếs surge como censura à idealização do caboclo e do campo, que, na literatura regionalista em voga em 1910, convertera o sertanejo em tipo ufanista equivalente ao índio romântico. Nesse sentido, o ensaio que dá título à coletânea "Urupês" 28 elegerá um símbolo grotesco para representar a miséria do camponês: "o sombrio urupê de pau podre" ${ }^{29}$. Espécie de monstro localizado na zona limítrofe entre a fauna e flora (na sua condição de fungo), o referido cogumelo, subterrâneo e disforme, emerge da crítica lobatiana ao proscênio da literatura como alegoria dessa figura inconvenientemente real do caboclo, vítima da ignorância e da fome, inadaptável, por um lado, à onda de progressismo que se abate sobre o país e, por outro, impermeável ao verniz de idealização pitoresca:

O caboclo é soturno. [...] No meio da natureza brasílica, tão rica de formas e cores, onde os ipês floridos derramam feitiços no ambiente e infolhescência dos cedros, às primeiras chuvas de setembro, abre a dança dos tangarás; onde há cor, perfume, vida dionisíaca em escachôo permanente, o caboclo é o sombrio urupê de pau podre a modorrar silencioso no recesso das grotas. Só ele não fala, não canta, não ri, não ama... Só ele no meio de tanta vida não vive... ${ }^{30}$

Com o disforme urupê, vem à tona seu universo, em que o elemento cômico e a nota caricaturesca, que compõem, por exemplo, o tipo do Jeca Tatu, celebrizado também pelo ensaio de Monteiro Lobato, trespassam, ao longo dos contos, enredos de violência extrema, que se desenrolam em um ambiente em que o chão é estéril, os casebres de sapé, o gado de costelas à mostra é eivado de bernes e a pobreza recebe contornos sinistros. Configura-se assim, como dito, uma cosmovisão disforme, matizada por tintas carregadas, uma exposição daquela realidade brasileira relegada à sombra pelo ufanismo da belle époque e, mesmo antes, pela tradição regionalista romântica. ${ }^{31}$ Tal cosmovisão, eventualmente, cede terreno ao monstruoso. Se, quando equiparado ao Jeca Tatu, o urupê serve de alegoria meramente caricaturesca e irônica à condição do caboclo, resvala no grotesco inquietante ao ligar-se também a Bocatorta, personagem do conto homônimo, habitante do mesmo ambiente que o Jeca, vítima do mesmo processo histórico de marginalização que ele, mas revestido pelos signos da monstruosidade explícita, do crime e mesmo por uma aura sobrenatural.
28. Publicado originalmente no jornal Estado de São Paulo, em 23 de 1914, ao lado de "Velha Praga" (que estampou, meses antes, o mesmo periódico), "Urupês" foi responsável pela celebridade de Monteiro Lobato como articulista polêmico.

O projeto original de Urupês contava com o título "Dez mortes trágicas", no entanto, por sugestão do colega Arthur Neiva, Lobato aproveita a fama adquirida com o ensaio, incorpora-o à obra, extraindo dele o título da coletânea de contos. Embora pareça algo fortuito, o ensaio Urupês, ao integrar o livro de contos trágicos e violentos, em sua maioria transcorridos em um ambiente rural miserável, acaba, como sugere João Luiz Ceccantini, por ditar "o tom" da obra. CECCANTINI, João Luís Tápias. "Cinquenta tons de verde: Urupês, o primeiro bestseller nacional", 2014, p. 46.

\section{LOBATO, Monteiro.} “Urupês", 1972, p. 155.

30. Ibidem. p. 155.

\section{No ensaio "Urupês",} Lobato, ao censurar a idealização do caboclo entre seus contemporâneos, remete explicitamente ao indianismo, alegando que "o indianismo está de novo a deitar copa, de nome mudado. Crismou-se 'caboclismo"', denunciando a genealogia romântica desse tipo popular em seu tempo. Cf. LOBATO, Monteiro. "Urupês", 1972, p. 146. Também numa das crônicas de Cidades Mortas, seu narrador, ao descrever as leituras populares na fictícia Oblivion, cidadezinha que representa a sátira de Lobato ao provincianismo do meio rural paulista, desfere ataques ao regionalismo romântico, em particular à obra de Bernardo Guimarães, autor que, segundo 
o narrador de Cidades Mortas: "falsifica o nosso mato. Onde toda gente vê carrapatos, pernilongos, espinhos, Bernardo aponta doçuras, insetos maviosos, flores olentes. Bernardo mente". Cf. LOBATO, Monteiro. Cidades Mortas, p. 28-29.

32. LOBATO, Monteiro.

"Bocatorta", 1972, p. 102.

33. Ibidem, p. 105.

34. Ibidem, p. 111.
Pode-se, pois, reconhecer uma gama variada de "urupês" em Lobato. De um lado estão aqueles que crescem mais à superfície, como o patriarca bêbado da família dos Nunes, de "A vingança da peroba", ou o Pedro Suã, de "Bucólica", que, apesar das histórias trágicas em que estão envolvidos (que, por circunstâncias distintas, envolvem a morte de seus filhos ainda crianças), ligam-se ao tipo do Jeca como estereótipo algo cômico (ao menos na pena de Lobato) do caipira ignorante, indolente e miserável. De outro, estão aqueles que crescem nas grotas mais profundas, onde vicejam a anormalidade e o crime. A esse tipo pertence Bocatorta. Com efeito, o conto "Bocatorta" demonstra que a cosmovisão de Urupês, quando extremada, toca o monstruoso - o protagonista da narrativa, na sua condição de negro e deformado, traz no corpo e na condição social a antítese do discurso eugênico comum aos primeiros anos do século XX, compartilhado por Lobato com tantos outros letrados da época. Nesse sentido, Bocatorta é uma monstrificação do Jeca.

O terror obsessivo que a jovem Cristina, filha do proprietário da fazenda onde vive Bocatorta, nutre pelo monstro é ilustrativo do simbolismo social que o envolve. Na ocasião em que seu noivo, Eduardo, em visita à fazenda do Atoleiro, demonstra curiosidade pela aberração, Cristina relembra os pesadelos de infância:

Bocatorta representara papel saliente em sua imaginação. Pequenita, amedrontavam-na as mucamas com a cuca, e a cuca era o horrendo negro. Mais tarde, com ouvir às crioulinhas todos os horrores correntes à conta dos seus bruxedos, ganhou inexplicável pavor ao notâmbulo. Houve tempo no colégio em que, noites e noites a fio, o mesmo pesadelo a atropelou. Bocatorta a tentar beijá-la, e ela, em transes, a fugir. Gritava por socorro, mas a voz lhe morria na garganta. Despertava arquejante, lavada em suores frios. Curou-a o tempo, mas a obsessão vincara fundos vestígios em su'alma. ${ }^{32}$

Cristina, cuja beleza se resume a "'linda', dito sem mais enfeites além do ponto da admiração" "33, opera, em relação a Bocatorta, um verdadeiro contraponto. Com efeito, o narrador explora com maestria, ao longo do conto, os contrastes entre essas duas personagens, de que é exemplar o momento em que o pai de Cristina, Major Zé Lucas, e o feitor Vargas deparam-se com Bocatorta beijando o cadáver da menina, após violar seu túmulo: "Um quadro hediondo antolhou-se-lhes de golpe: um corpo branco jazia fora do túmulo - abraçado por um vulto vivo, negro e coleante como o polvo" ${ }^{34}$. As impressões incertas da noite são traduzidas na perspectiva oblíqua do narrador, que reduz o contraste entre os corpos ao claro-escuro. Além disso, o componente de asco e materialidade necessário à figuração do 
monstruoso não deixa de se imprimir no vulto de Bocatorta: ele é "vivo", "coleante como o polvo" - o efeito da aparição do vulto não visa atingir os olhos, mas o tato, imprimindo no leitor sensação invasiva das ventosas de um molusco.

As coincidências trágicas que levam a jovem (morta em consequência de uma pneumonia adquirida em viagem ao sítio do aleijão) a ser beijada por Bocatorta tangem não apenas a interditos sexuais, mas também sociais. Bocatorta macula com sua emblemática boca, epicentro de todo o horror provocado por sua figura, essa jovem que concentra todos os ideais de beleza e valores das elites brasileiras. Bela, jovem, branca, pertencente à classe dos proprietários, Cristina compõe ao lado de Bocatorta quadro semelhante às estampas de fins da Idade Média com o motivo a morte e a donzela ${ }^{35}$, mas adequado ao contexto brasileiro. Diferentemente do que ocorre com esse motivo macabro, o beijo de Bocatorta não conspurca a vida com o horror da morte, mas os atributos da elite econômica resumidos em Cristina com pobreza, doença e marginalidade - elementos materializados no corpo do negro deformado.

De acordo com as investigações de Claude Kappler, o juízo sobre a monstruosidade é relativo, dependendo do lugar de que é emitido. Contudo, desde as primeiras especulações sobre esse fenômeno, o monstruoso liga-se à infração da normalidade. Remetendo ao tratado sobre a Geração dos Animais, de Aristóteles, Kappler demonstra que, já na antiguidade, o monstro constitui uma espécie de exceção, ou mesmo acidente, ao processo de geração dos organismos ${ }^{36}$. Segundo Aristóteles, a geração de vida está subordinada à disputa entre dois princípios, um masculino e paradigmático, a Forma, e outro feminino, amorfo e matricial, a Matéria. Se a Forma triunfa sobre a Matéria, surge um organismo masculino, "perfeito". Se o princípio da Matéria tem proeminência no processo, muitas possibilidades se abrem: desde o surgimento de fêmeas, tratadas por Aristóteles não como monstros de fato, mas espécie de "macho castrado", até a geração de monstros strictu sensu ${ }^{37}$.

A partir dos postulados de Aristóteles, é possível depreender o lugar que o monstro ocupa na existência - na condição de atestado do triunfo da Matéria, o monstro coloca-se na instância oposta ao paradigma e, consequentemente, da ordem; avesso dos ideais transcendentes e da anima, é matéria em sua imanência, o corpo e a carne que assumem dimensões absolutas. Talvez intuindo isso, Augusto dos Anjos tenha materializado a dissonância de sua poesia no corpo disforme; e Lobato, ao explorar o reverso dos modelos sociais de sua época, em sua investigação da miséria do campo, desenterra das grotas o monstruoso "Bocatorta". Negro, descendente de escravos, miserável e deformado, o personagem de Lobato é um antípoda de carne da eugenia
35. Ligadas a outros motivos que atestam o triunfo da morte sobre a vaidade, como a Dança Macabra, as representações da Morte e a donzela tornar-se-ão populares a partir do século XIV, apresentando normalmente um esqueleto arrastando uma bela jovem ao túmulo, muitas vezes em atitude de conotações sexuais. Cf. SCHMITT, JeanClaude. Os vivos e os mortos na sociedade medieval, 1999. Artistas do renascimento germânico popularizarão o tema, que chegará a obras famosas da modernidade, como os trabalhos de Edward Munch e Egon Schiele.

36. KAPPLER, Claude. Monstruos, demonios y maravillas a fines de la edad media, 2004.

37. Aristóteles, apud. KAPPLER, Claude. Monstruos, demonios y maravillas a fines de la edad media, 2004, p. 236-237. 
38. LOBATO, Monteiro,

"Bocatorta", 1972, p. 102. e do progresso e também concentra um horror que excede as próprias possibilidades da linguagem - ele subverte, pois, todos os modelos, sociais e discursivos. Antes de concluir: "aquilo é feiúra que só vendo", Vargas, capataz da fazenda do Atoleiro, tenta pintar a Eduardo um retrato de Bocatorta:

Vossa Senhoria 'garre um juda de carvão e judie dele; cavoque o buraco dos olhos e afunde dentro duas brasas alumiando; meta a faca nos beiços e saque fora os dois; 'ranque os dentes e só deixe um toco; entorte a boca de viés na cara; faça uma coisa desconforme, Deus que me perdoe. Depois, como diz o outro, vá judiando, vá entortando as pernas e esparramando os pés. Quando cansar, descanse. Corra o mundo campeando feiúra braba e aplique o pior no estupor. Quando acabar 'garre no juda e ponha rente de Bocatorta. Sabe o que acontece? O juda fica lindo!.... ${ }^{38}$

A aparência de Bocatorta não se curva aos imperativos da palavra, obrigando Vargas a comunicá-la por via oblíqua e negativa: o mais feio dos Judas de carvão é belo diante dele. A despeito da tonalidade cômico-grotesca da descrição, o posterior contato com Bocatorta em sua imanência demonstra a insuficiência do discurso diante da experiência real da monstruosidade:

Bocatorta excedeu a toda pintura. A hediondez personificara-se nele, avultando, sobretudo, na monstruosa deformação da boca. Não tinha beiços, e as gengivas largas, violáceas, com raros cotos de dentes bestiais fincados às tontas, mostravam-se cruas, como enorme chaga viva. E torta, posta de viés na cara, num esgar diabólico, resumindo o que o feio pode compor de horripilante. Embora se lhe estampasse na boca o quanto fosse preciso para fazer daquela criatura a culminância da ascosidade, a natureza malvada fora além, dando-lhe pernas cambaias e uns pés deformados que nem remotamente lembravam a forma do pé humano. E olhos vivíssimos, que pulavam das órbitas empapuçadas, veiados de sangue na esclerótica amarela. E pele grumosa, escamada de escaras cinzentas. Tudo nele quebrava o equilíbrio normal do corpo humano, como se a teratologia caprichasse em criar a sua obra-prima.

"Bocatorta", como dito, não pode ser incluído em qualquer norma da natureza, da sociedade ou do discurso mimético. O que permite concluir que a explicitação do horror presente no fenômeno do monstro consiste em uma hipérbole do real - como já postulara Aristóteles, o monstro nasce do triunfo da imanência sobre o paradigma transcendente, de onde provém os modelos. Talvez por isso, a busca de Monteiro Lobato pela autenticidade do registro das condições de vida do homem do campo tenha aberto sua linguagem à distorção - a deformação 
do real em Urupês, pode-se dizer, nasce de um processo de íntima proximidade com os fenômenos e de um esforço realista que reconhece a insuficiência das convenções da linguagem para tratar de determinadas realidades; por isso, o retrato cru que pretende do campo dispensa as convenções literárias da época, demandando novo código, que recorre à ironia, ao grotesco e à deformação e parece realizar-se plenamente na estética do monstruoso de "Bocatorta", conto que reflete, a seu modo, a conhecida "crise da representação" comum à ficção moderna".

A dinâmica que gera o monstro também remete à aleatoriedade e ao caos; ao transgredir os modelos, os monstros são a afirmação perturbadora de que a natureza está sujeita a princípios incompreensíveis. Mesmo os monstros reais remetem, pois, ao mistério, sendo, amiúde, envolvidos pela aura do fantástico. Bocatorta está entre esses monstros, outsider por excelência, exceção a tudo que é regular, sua monstruosidade não o marginaliza apenas em relação à vida social, mas o aparta da própria condição humana. Seu lugar no mundo confina, pelo menos no imaginário do povo da fazenda do Atoleiro, com o sobrenatural; como testemunha, o Major Zé Lucas:

- Bocatorta é a maior curiosidade da fazenda, respondeu o major. Filho duma escrava de meu pai, nasceu, o mísero, disforme e horripilante como não há memória de outro. Um monstro, de tão feio. Há anos que vive sozinho, escondido no mato, donde raro sai e sempre de noite. O povo diz dele horrores - que come crianças, que é bruxo, que tem parte com o demo. Todas as desgraças acontecidas no arraial, correm-lhe por conta. Para mim, é um pobre diabo cujo crime único é ser feio demais. Como perdeu a medida, está a pagar o crime que não cometeu. ${ }^{40}$

Bocatorta recebe da imaginação coletiva atributos que demonstram a condição limítrofe entre a maravilha natural e a irrupção do sobrenatural que pesa sobre os monstros, na medida em que a deformidade abre o corpo ao mistério do desconhecido. A personagem exerce no conto a função de centro de onde irradia toda uma atmosfera que envolve com densa carga de estranhamento e desorientação o ambiente rural reconstruído aos retalhos pelos contos de Urupês, tornando anômalo aquilo que é familiar. Nesse sentido, o conto liga-se intimamente ao conceito de grotesco cunhado por Wolfgang Kayser:

O mundo do grotesco é o nosso mundo - e não é. O horror mesclado ao sorriso tem seu fundamento justamente na experiência de que nosso mundo confiável, aparentemente arrimado numa ordem bem firme, se alheia sob a irrupção de poderes abismais, se desarticula nas juntas e das formas e dissolve em suas ordenações. ${ }^{41}$
39. As diversas estratégias utilizadas pela ficção realista para promover um registro autêntico do real, distanciando-se das convenções da objetividade, são tratadas por Tânia Pellegrini como atitudes modernas que se colocam críticas diante da pretensão à univocidade do discurso ficcional. Cf. PELLEGRINI, Tânia.

"Realismo postura e método". Letras de hoje, 2007, p. 137-155.

40. LOBATO, Monteiro. "Bocatorta", 1972, p. 101.

41. KAYSER, Wolfgang. O grotesco: sua configuração na pintura e na literatura, 2003, p. 40. 
42. BAKHTIN, Mikhail. Cultura popular na idade média e renascimento: o contexto de François Rabelais, 2013, p. 277.

43. LOBATO, Monteiro.

"Bocatorta", 1972, p. 100.
Localizada em lugar intermediário entro o riso e o horror, e tendo evoluído na expressão moderna de motivo cômico extravagante para uma modalidade de expressão de tudo o que é perturbador, a categoria do grotesco pode ser interpretada como uma forma de representação da realidade sensível ao anômalo. É nas paragens do grotesco que o monstro encontra lugar cativo como motivo estético, concentrando todas as ambiguidades dessa categoria que remete ao fantástico, à caricatura disforme, à hibridação e aos elementos relegados à esfera do feio e do inconveniente, como o baixo-corporal interpretado por Bakhtin como motivos risíveis do realismo grotesco ${ }^{42}$. De acordo com a leitura de Kayser, pode-se deduzir que os mesmos efeitos de mal-estar e desorientação provocados pelos corpos grotescos (que concentram asco, riso, horror), quando galgam esferas mais amplas, como a dos acontecimentos e do ambiente, compõem uma cosmovisão integrada em que o estranho ameaça as nossas certezas.

No conto de Lobato, não gratuitamente, o monstro Bocatorta está integrado ao ambiente, imprimindo sua incômoda presença em toda a fazenda do Atoleiro. Seu correlato espacial é o pântano que surge no começo da narrativa. Sob aparência de um brejo vulgar, esconde um profundo abismo que já tragou animais e até, afiança o povo, um homem, o que o torna um lugar maldito, imaginado por todos como: "uma das bocas do próprio inferno" "33. O pântano surge precisamente como antítese grotesca do bucolismo; ele representa tudo que há de feio e perigoso no campo. Bocatorta, por seu turno, também representa tudo que há de feio nas massas desprezadas que vivem no sertão; é, como já mencionado, a antítese dos ideais de raça e civilidade da belle époque, escondendo, sob sua triste condição, a atividade criminosa da necrofilia. Como o pântano, Bocatorta também se resume a uma boca horrenda. Unindo-se ao abismo, a boca disforme torna-se motivo central do conto. A boca é o aspecto mais hediondo da aparência do Bocatorta; o beijo será o gesto de profanação dos interditos sociais e morais que subjazem ao conto; por fim, será na boca do pântano, tragicamente anunciada no início da narrativa, que Bocatorta será lançado para a morte, como punição por seu crime. O pântano e Bocatorta, pois, concentram em seus corpos monstruosos universos de horror, obsessão, miséria, fatalidade, sugestões sobrenaturais que configuram o conto - também não de maneira gratuita, o pântano sugere o nome à fazenda, Atoleiro, assim como Bocatorta dá título à narrativa.

Se for possível concentrar em um todo coerente a avaliação feita por Lobato das condições de vida no campo desde o artigo "Urupês" até "Bocatorta", depreende-se uma visão grotesca da realidade que, ao expor o oposto das expectativas da belle époque 
brasileira, encontra síntese na imagem do corpo monstruoso: seja o do abjeto urupê de pau podre, seja do negro deformado. Nesse sentido, "Bocatorta" corresponderia a uma espécie de afunilamento da mesma perspectiva que levou a poesia de Augusto dos Anjos a buscar no fenômeno da monstruosidade as cifras para a interpretação das angústias existenciais de sua época. Daí ser possível encontrar em Eu e alguns momentos de Urupês uma tentativa de revelar o lado oculto da belle époque na forma de um corpo monstruoso.

É possível dizer que a ciência moderna tentou domar o monstro, reduzindo à patologia o que antes fora tratado como manifestação do maravilhoso. Conscientes dos imperativos de seu tempo, Augusto dos Anjos e Monteiro Lobato, quando contemplam o fenômeno da monstruosidade, buscam reabilitar o fascínio que lhe é inerente, convertendo o monstro em alegoria de aspectos da sociedade brasileira convenientemente banidos dos modelos de cultura moderna. Pode-se dizer que seus escritos aqui tratados "reencantam" como forma de denunciar as mistificações com que a modernidade inscreveu-se entre nós; mistificações essas a que são convenientes o decoro literário do qual os dois escritores se afastam. A presença do monstruoso em Eu e Urupês, por isso, exige novas técnicas de composição literária, seja para que as inquietações filosóficas e metafísicas do nascente século XX possam se tornar motivos poéticos autênticos, como na lírica de Augusto dos Anjos, seja para a composição de um retrato franco da realidade, como em Monteiro Lobato. Ao lançarem seus monstros sobre a paisagem social e ideológica do Brasil, Augusto dos Anjos e Monteiro Lobato acabam por expor toda a "feiura" que medra no corpo de nossa história, conspurcando com inventividade e franqueza tudo que há de postiço no projeto de modernização país.

\section{Referências}

ANJOS, Augusto dos. Eu e outras poesias. Rio de Janeiro:

Bertrand Brasil, 2010.

BAKHTIN, Mikhail. Cultura popular na idade média e renascimento: o contexto de François Rabelais. Tradução de Yara Frateschi Vieira. São Paulo: Huicitec, 2013.

BARROS, Eudes. A poesia de Augusto dos Anjos: uma análise de psicologia e estilo. Rio de Janeiro: Gráfica Ouvidor Editora, 1974. 
BAUDELAIRE, Charles. Les Fleurs du Mal. Prefáces d'André Gide et de Théophile Gautier. Rio de Janeiro: Libraire Victor, 1942.

BENJAMIN, Walter. Origem do drama trágico alemão. Tradução de João Barrento. Belo Horizonte: Autêntica Editora, 2013.

BERARDINELLI, Alfonso. Da poesia à prosa. Organização e prefácio de Maria Betânia Amoroso; tradução Maurício Santana Dias. São Paulo: Cosac Naify, 2007.

BOSI, Alfredo. O Pré-modernismo. São Paulo: Cultrix, 1973.

CECCANTINI, João Luís. "Cinquenta tons de verde: Urupês, o primeiro best-seller nacional”. In: LAJOLO, Marisa (Org.). Monteiro Lobato, livro a livro (obra adulta). São Paulo: Editora UNESP, 2014.

FREUD, Sigmund. "O Estranho (1919)". In: História de uma neurose infantil. E. S. B., v. XVII. Tradução de Eudoro Augusto Macieira de Souza. Rio de Janeiro: Imago, 1996. p. 237-269.

FRIEDRICH, Hugo. Estrutura da lírica moderna: metade do século XIX a meados do século XX. Tradução de Marisa M. Curioni (texto) e Dora F. da Silva (poesias). São Paulo: Duas Cidades, 1978.

JURKOV, Tania. "Blood, Monstrosity and Violent Imagery: Grand-Guignol, the French Theatre of Horror as a Form of Violent Entertainment". [sic] a journal of literature, culture and literary translation. n. 1, p. 1-15, dez. 2013.

KAPPLER, Claude. Monstruos, demonios y maravillas a fines de la edad media. Tradução de Julio Rodríguez Puértolas. Madri: Tres Cantos, 2004.

KAYSER, Wolfgang. O Grotesco: configuração na pintura e na literatura. Tradução de J. Guinsburg. São Paulo: Perspectiva, 2003.

KOOZIN, Kristine. The Vanitas Still Lifes of Harmen Steenwick (1612-1656): Metaphoric Realism. New York: The Edwin Mellen Press, 1990.

LOBATO, Monteiro. Cidades Mortas. São Paulo: Globo, 2009. Urupês. São Paulo: Brasiliense, 1972.

NEEDELL, Jeffrey. Belle époque tropical: sociedade e cultura da elite do Rio de Janeiro na virada do século. Tradução de Celso Nogueira. São Paulo: Companhia das Letras, 1993. 
OEHELER, Dolf. Quadros parisienses (1830-1848): estética antiburguesa em Baudelaire, Daumier e Heine. Tradução de José Macedo e Samuel Tintan Jr. São Paulo: Companhia das Letras, 1997.

PAES, José Paulo. "O art nouveau na literatura brasileira". In:__ Armaźém literário - Ensaios. Organização e apresentação de Vilma Arêas. São Paulo: Companhia das Letras, 2008, p. 75-95.

"Uma microscopia do monstruoso". In:

Armazém literário - Ensaios. Organização e apresentação de Vilma Arêas. São Paulo: Companhia das Letras, 2008b, p. 96-104.

PELLEGRINI, Tânia. "Realismo postura e método". Letras de boje, n. 4, p. 137-155, dez. 2007.

RIMBAUD, Arthur. CEuvres complètes. Paris: Gallimard, 1972, p. 260.

SCHMITT, Jean-Claude. Os vivos e os mortos na sociedade medieval. Tradução de Maria Lúcia Machado. São Paulo: Companhia das Letras, 1999.

SCHWARZ, Roberto. Ao vencedor as batatas: forma literária e processo social nos inícios do romance brasileiro. São Paulo: Duas Cidades, 1977. 
